\title{
In vitro Evaluation of Persistent Toxicity of Imidacloprid 600 FS against Brown Plant Hopper and Green Leaf Hopper and its Impact on Germination and Seedling Vigour in Rice
}

\author{
S. Sangamithra*, K. Samiayyan and S. Chandrasekaran \\ Department of Agricultural Entomology, Tamil Nadu Agricultural University, \\ Coimbatore, India \\ *Corresponding author
}

\section{A B S T R A C T}

Keywords

Persistence, imidacloprid, Seed treatment, Brown plant hopper and green leaf hopper

Article Info

Accepted:

26 December 2017

Available Online:

10 January 2018
The laboratory experiment was conducted to investigate the persistence of imidacloprid $600 \mathrm{FS}$ against brown plant hopper and green leaf hopper, to standardize the incubation period of paddy seeds before seed treatment and impact on germination and seedling vigour. The results revealed that twenty hours incubation period before treatment is finest and does not affect germination percentage. Moreover seed treatment did not influence seedling length and vigour. The imidacloprid treated plants @ $2.5 \mathrm{ml} \mathrm{kg}^{-1}$ seed exhibited higher persistence up to 50 days against brown plant hopper and green leaf hopper.

\section{Introduction}

Imidacloprid 1[(6-chloro-3-pyridynyl)methyl] $-4-5$ - dihydro - $\mathrm{N}$ - nitro - $1 \mathrm{H}$ - imidazole - 2 amine] is a neonicotinoid insecticide belonging to the chloronicotinyl subfamily (Kagabu et al., 1992). The discovery of imidacloprid by Shinzo Kagabu, and its subsequent market introduction in 1991, started the era of the neonicotinoid class of insecticides (Tomizawa and Casida, 2011). It is the most important neonicotinoid used primarily as a systemic compound against sucking and some biting insect pests (rice hoppers, aphids, thrips, whitefly, termites, etc. (Sur and Stork, 2003). Their physicochemical characteristics, mainly assessed in terms of their octanol water partition coefficient $\left(\mathrm{K}_{\mathrm{ow}}\right)$ and dissociation constant $(\mathrm{pKa})$, enable their entrance into plant tissues and their translocation to all its parts (Bromilow and Chamberlain, 1995; Bonmatin et al., 2014). Regardless of the manner of application and route of entry to the plant, they translocate throughout all plant tissues making them toxic to any insects (and potentially other organisms) that feed upon the plant. 
In Asia, major large-scale applications of neonicotinoids include spraying of rice fields and other crops (Taniguchi et al., 2012), as well as granular applications (Thuyet et al., 2011, 2012) and seed coatings. By far, the largest and most popular application in crop protection is the prophylactic seed coating. It is an a prior treatment against target pests that may decrease production yields. During germination and growing, the active substance in the seed coating is taken up by the roots and translocated to all parts of the crop, making the crop toxic to insects that attempt to feed upon it (Van der Sluijs et al., 2013). Nevertheless, this group have a wide array of application modes as soil, seed and foliar treatments, seed treatment attains predilection since for convenience and safety for agriculturists. Besides copious merits of seed treatment over foliar spray, impact of seed treatment on germination, seedling vigour and its persistence in plant system is not comprehensible. Keeping this scientific scope, the present experiment was undertaken in laboratory condition, TNAU, Coimbatore to study the effect in germination, seedling vigour and persistence against brown plant hopper and green leaf hopper.

\section{Materials and Methods}

\section{Evaluation of persistent toxicity of imidacloprid 600 FS}

Pot culture experiments were conducted in the glass house at the insectary of Dept. of Agrl. Entomology, TNAU in order to assess the persistent toxicity of imidacloprid $600 \mathrm{FS}$ as seed treatment against brown plant hopper and green leaf hopper

\section{Insect culture maintenance}

The culturing of plant hoppers was done as per the method described by Heinrichs et al (1985) Nucleus population of brown plant hopper (BPH) Nilaparvata lugens Stal. and sgreen leaf hopper (GLH), Nephotettix virescens Distant. were collected from the fields of Paddy Breeding Station, TNAU, Coimbatore from unsprayed fields. In order to maintain a uniform and continuous culture of the hoppers for the use in experiments, the insects were mass cultured in potted $\mathrm{TN}_{1}$ rice plants. Thirty days old rice seedlings, in which outer leaf sheaths and dried leaf parts were removed to destroy any possible oviposition by other insects were planted in plastic pots (10 $\mathrm{cm}$ height and $11.5 \mathrm{~cm}$ diameter). The potted plants were transferred to a large wooden cage and adult insects collected from field were released into the cage for mass multiplication. During the whole process of culturing, the potted plants were placed in the plastic basins with $10-15 \mathrm{~cm}$ depth of water. By this way, the relative humidity to the growing plants was maintained. The plants showing wilting symptoms due to nymphal feeding were replaced regularly with healthy seedlings of paddy from the rearing cages.

\section{Method of assessment}

The healthy and viable paddy seeds of ADT 43 for persistent toxicity study were obtained from Paddy Breeding Station, TNAU, Coimbatore. The experiment was conducted in a completely randomized design with five replications. The treatments included for the study were as follows

\begin{tabular}{lll}
\hline No. & Treatments & Dose $\left(\mathrm{ml} \mathrm{kg}^{-1}\right)$ \\
\hline 1 & Imidacloprid 600 FS & 1.5 \\
2 & Imidacloprid 600 FS & 2.0 \\
3 & Imidacloprid 600 FS & 2.5 \\
4 & Imidacloprid 600 FS & $2.0 \quad$ P.flourescens \\
5 & Thiamethoxam 300 FS & 3.0 \\
6 & Untreated control & 0.0 \\
\hline
\end{tabular}


Fifty gram of seeds were soaked in $500 \mathrm{ml}$ of water for 24 hours. The homogenous slurry of respective treatment was prepared by using 1 $\mathrm{ml}$ of distilled water which was equivalent to the doses mentioned above. The pre germinated seeds were treated with above prepared slurry and sown in the plastic pot (10 $\mathrm{cm}$ height and $11.5 \mathrm{~cm}$ height). The pots were placed in the plastic tray with $10-15 \mathrm{~cm}$ depth of water throughout the experiment. When the seedlings were 20-25 days old, plants were covered with cylindrical mylar film cages (38 $\mathrm{cm}$ height and $14.2 \mathrm{~cm}$ dia) with fine mesh screen windows. Ten individuals of third instar BPH and GLH were released separately in each pot.

The number of surviving insects in each pot was counted at 48 hours interval and fresh set of 10 individuals were released on each day of count after removing the insects released on the previous day. The procedure was followed, till no mortality on the treated plants was observed. In both the cases, mortality data were corrected with Abbott's formula (Abbott, 1925).

Corrected per cent mortality $=\frac{\mathrm{Pt}-\mathrm{P}_{\mathrm{c}}}{100-\mathrm{P}_{\mathrm{c}}}$ Where,

$\mathrm{Pt}$ - Observed per cent mortality in treatment $\mathrm{P}_{\mathrm{c}}-$ Observed per cent mortality in untreated check

Persistence toxicity $=$ Average residual toxicity $\mathrm{x}$ Period for which the toxicity persisted (days).

\section{Standardization of incubation hours for pre germination}

The seeds of ADT 43 for the experiment were procured from Paddy Breeding Station, TNAU, Coimbatore. Five hundred gram of seeds were soaked for 24 hours. After soaking, seeds were incubated in darkness. Different hours of incubation were considered as factor with eight replications and experimental details are enclosed hereunder.

\begin{tabular}{ll} 
No. & $\begin{array}{l}\text { Treatment } \\
\text { (Incubation time ) }\end{array}$ \\
\hline 1 & 24 hours incubation \\
2 & 48 hours incubation \\
3 & 72 hours incubation \\
\hline
\end{tabular}

\section{Germination percentage}

Four replicates of 100 seeds each were selected at random from each treatment and placed for germination in roll towel medium at uniform spacing and kept in the germination room maintained at of $25 \pm 1^{\circ} \mathrm{C}$ and $95 \pm 3 \%$ $\mathrm{RH}$ and the seedlings were evaluated on the $14^{\text {th }}$ day by enumerating all the normal seedlings and expressed as germination percentage (ISTA, 1999).

\section{In vitro evaluation of imidacloprid $600 \mathrm{FS}$ on germination and seedling vigour}

The effect of imidacloprid 600 FS on germination and seedling vigour at standardised hour of incubation was evaluated with eight replications and treatment details are given hereunder. Dry seed treatment was maintained as absolute control. The dosage used for this experiment was $2.5 \mathrm{ml} \mathrm{kg}^{-1}$ seed. In case of dry seed treatment, seed without soaking and incubation, was mixed with imidacloprid and subjected to germination.

\begin{tabular}{ll}
\hline No. & Treatment \\
\hline 1 & $\begin{array}{l}24 \text { hours incubation }+ \text { imidacloprid } \\
\text { treatment }\end{array}$ \\
2 & $\begin{array}{l}\text { Imidacloprid treatment }+24 \text { hours } \\
\text { incubation } \\
3\end{array}$ \\
\end{tabular}




\section{Germination Percentage}

As per the method described in 2(a).

\section{Root length}

At final count ( $14^{\text {th }}$ day), ten normal seedlings in each replication were chosen at random and length of root was measured from collar region to tip of the primary root and the mean values were expressed in centimeter.

\section{Shoot length}

The same normal ten seedlings in which root length was measured were used to measure shoot length.

The length of shoot was measured from the base of the shoot to tip of the primary leaf and the mean values were expressed in centimeter.

\section{Vigour index}

The vigour index of the seedling was computed using the formula suggested by Abdul-Baki and Anderson (1973) and expressed in whole number.

Vigour index $=$

Germination (\%) x Mean seedling length $(\mathrm{cm})$

\section{Statistical analysis}

The data on germination percentage of each treatment were subjected to arcsine transformation for statistical analysis while data of root and shoot length were analysed as same without any transformation.

Critical difference values were calculated at five per cent probability level and mean values were compared by using Duncan's Latin Square Design (1951).

\section{Results and Discussion}

\section{1) Persistent toxicity}

Ninety per cent mortality of BPH was observed up to 13 days of observation in 2.5 $\mathrm{ml} \mathrm{kg}$ and up to 11 days in $2.0 \mathrm{ml} \mathrm{kg}$ of imidacloprid. There was no marked difference of BPH mortality observed in the treatment combination viz., imidacloprid $2.0 \mathrm{ml}+10 \mathrm{~g}$ Pseudomonas flourescens and imidacloprid alone at $2.0 \mathrm{ml} \mathrm{kg}^{-1}$. The standard check thiamethoxam $\left(3.0 \mathrm{ml} \mathrm{kg}^{-1}\right)$ and lowest dose of imidacloprid $\left(1.5 \mathrm{ml} \mathrm{kg}^{-1}\right)$ registered mortality range of 81-89 per cent up to 13 days . Thiamethoxam $\left(3.0 \mathrm{ml} \mathrm{kg}^{-1}\right)$ recorded 85 per cent mortality while it was 81 per cent in imidacloprid $\left(1.5 \mathrm{ml} \mathrm{kg}^{-1}\right)$. Above fifty per cent mortality was observed up to 21 days in imidacloprid $\left(2.5 \mathrm{ml} \mathrm{kg}^{-1}\right)$ while it was 19 days in imidacloprid $\left(2.0 \mathrm{ml} \mathrm{kg}^{-1}\right)$ and 17 days with thiamethoxam $\left(3.0 \mathrm{ml} \mathrm{\textrm {kg } ^ { - 1 }}\right)$ and imidacloprid $\left(1.5 \mathrm{ml} \mathrm{kg}^{-1}\right)$. The mortality of BPH was there up to 31 days with imidacloprid $\left(2.5 \mathrm{ml} \mathrm{kg}^{-1}\right)$. The order of relative efficacy (ORE) of the insecticides based on the persistent toxicity index (PTI) was: imidacloprid at $2.5>2.0 \mathrm{ml} \mathrm{kg}^{-1}>2.0 \mathrm{ml}$ $+10 \mathrm{~g}$ Pseudomonas flourescens $\mathrm{kg}^{-1}>$ thiamethoxam at $3.0 \mathrm{ml} \mathrm{kg}^{-1}>$ imidacloprid at $1.5 \mathrm{ml} \mathrm{kg}^{-1}$ (Table 3).

Regarding green leaf hopper results observed was similar with BPH. The results Ninety per cent mortality was observed up to 11 days of observation in higher dose of imidacloprid at $2.5 \mathrm{ml} \mathrm{kg}{ }^{-1}$ seed and eighty per cent mortality was recorded up to 15 days. This was followed by imidacloprid at $2.0 \mathrm{ml} \mathrm{kg}^{-1}$ which registered eighty per cent mortality up to 13 days. There was no pronounced significant effect in mortalty between the imidacloprid at $2.0 \mathrm{ml} \mathrm{kg}{ }^{-1}$ alone and combination of imidacloprid at $2.0 \mathrm{ml}+10 \mathrm{~g}$ P. flourescens $\mathrm{kg}^{-1}$. Above fifty per cent mortality was observed up to 23 days in imidacloprid at 2.5 
$\mathrm{ml} \mathrm{kg}^{-1}$ while it was 21 days in imidacloprid at $2.0 \mathrm{ml} \mathrm{kg}{ }^{-1}$ and imidacloprid at $2.0 \mathrm{ml}+10 \mathrm{~g}$ $P$. flourescens $\mathrm{kg}^{-1}$ and 19 days with imidacloprid at $1.5 \mathrm{ml} \mathrm{kg}$-1 and standard check thiamethoxam at $3.0 \mathrm{ml} \mathrm{kg}$. In the higher dose of imidacloprid viz., $2.5 \mathrm{ml} \mathrm{kg}$, mortality persisted up to 31 days (Table 4).

\section{2) Standardisation of incubation hours for pregermination}

The results of the standardisation of incubation hours are shown in the Table 1. The higher germination percentage was recorded after 24 hours incubation (96 per cent) followed by 48 hours incubation (90 per cent). Comparatively germination percentage was lower with 72 hours incubation (81 per cent). Hence 24 hours incubation was choosen as a standard for subsequent study.

\section{3) In vitro evaluation of imidacloprid 600 FS on germination and seedling vigour}

The influence of imidacloprid 600 FS on germination and seedling vigour was not statistically significant at $\mathrm{CD} \quad(\mathrm{P}=0.05)$. However, twenty four hours incubation after imidacloprid treatment exhibited trivial lofty root and shoot length of 18.46 and $8.52 \mathrm{~cm}$, respectively. Besides, it did not affect germination percentage (97 per cent) (Table 2).

Table.1 Standardisation of incubation hours for pre germination of rice

\begin{tabular}{|c|c|c|}
\hline SI.No. & $\begin{array}{c}\text { Treatments } \\
\text { (Incubation time) }\end{array}$ & $\begin{array}{c}\text { Rice seed Germination } \\
\text { percentage* }(\%)\end{array}$ \\
\hline 1 & $24 \mathrm{hrs}$ & $96^{\mathrm{a}}$ \\
& & $(80)$ \\
\hline 2 & $48 \mathrm{hrs}$ & $90^{\mathrm{b}}$ \\
& & $(71)$ \\
\hline 3 & $72 \mathrm{hrs}$ & $81^{\mathrm{c}}$ \\
& & $(64)$ \\
\hline 4 & $\mathbf{C D}(\mathbf{P}=\mathbf{0 . 0 5})$ & $\mathbf{4 . 0 1}$ \\
\hline
\end{tabular}

*Values of rice germination percentage are mean value of eight observations Values in parentheses are arc sine transformed values of eight observations

Table.2 Invitro evaluation of imidacloprid 600 FS on germination and seedling vigour of rice

\begin{tabular}{|c|c|c|c|c|c|}
\hline Sl.No. & Treatments & $\begin{array}{c}\text { Germination } \\
\text { percentage }(\%)\end{array}$ & $\begin{array}{c}\text { Root } \\
\text { length } \\
(\mathbf{c m})\end{array}$ & $\begin{array}{c}\text { Shoot } \\
\text { length } \\
(\mathbf{c m})\end{array}$ & $\begin{array}{c}\text { Vigour } \\
\text { index }\end{array}$ \\
\hline 1 & $\begin{array}{c}24 \text { hrs incubation }+ \\
\text { imidacloprid treatment }\end{array}$ & $\begin{array}{c}96 \\
(82)\end{array}$ & 18.04 & 7.92 & 2503 \\
\hline 2 & $\begin{array}{c}\text { Imidacloprid treatment } \\
\text { 24 hrs incubation }\end{array}$ & $\begin{array}{c}97 \\
(81)\end{array}$ & 18.46 & 8.52 & 2603 \\
\hline $\mathbf{3}$ & $\begin{array}{c}\text { Absolute control (Dry seed } \\
\text { treatment) }\end{array}$ & $\begin{array}{c}96 \\
(78)\end{array}$ & 17.35 & 7.48 & 2377 \\
\hline $\mathbf{4}$ & $\mathbf{C D}(\mathbf{P = 0 . 0 5})$ & $\mathbf{N S}$ & $\mathbf{N S}$ & $\mathbf{N S}$ & $\mathbf{N S}$ \\
\hline
\end{tabular}

Values in parentheses are arc sine transformed values of eight observations 
Table.3 Persistent toxicity of imidacloprid 600 FS to brown planthopper, Nilaparvata lugens (Stal) on rice

\begin{tabular}{|c|c|c|c|c|c|c|c|c|c|c|c|c|}
\hline \multirow[t]{2}{*}{ Treatment } & \multirow{2}{*}{$\begin{array}{l}\text { Dose }(\mathrm{ml} / \mathrm{g} \\
\left.\mathrm{kg}^{-1} \text { seed }\right)\end{array}$} & \multicolumn{11}{|c|}{ Corrected per cent mortality / Period (Days After Treatment) } \\
\hline & & 1 & 3 & 5 & 7 & 9 & 11 & 13 & 15 & 17 & 19 & 21 \\
\hline Imidacloprid 600 FS & 1.5 & 87.6 & 87.5 & 87.3 & 87.3 & 87.1 & 85 & 81.2 & 69.4 & 53.2 & 46.3 & 39.7 \\
\hline Imidacloprid 600 FS & 2.0 & 90.3 & 90.1 & 90.1 & 90.0 & 90.0 & 90.0 & 88.3 & 77.2 & 65.3 & 50.5 & 48.2 \\
\hline Imidacloprid 600 FS & 2.5 & 91.2 & 91 & 91 & 91 & 91 & 90.7 & 90.0 & 80.3 & 71.0 & 55.1 & 51.4 \\
\hline $\begin{array}{l}\text { Imidacloprid } 600 \mathrm{FS}+P \text {. } \\
\text { fluorescens }\end{array}$ & $2.0+10 \mathrm{~g}$ & 90.0 & 90.0 & 89.8 & 89.7 & 89.7 & 89.5 & 88.0 & 76.8 & 64.1 & 51.3 & 45.1 \\
\hline Thiamethoxam 300 FS & 3.0 & 89.4 & 89.1 & 89.1 & 89.1 & 89.0 & 88 & 85 & 72.1 & 59.7 & 48.4 & 43.6 \\
\hline
\end{tabular}

\begin{tabular}{|c|c|c|c|c|c|c|c|c|c|c|c|}
\hline \multirow{2}{*}{ Treatment } & \multirow{2}{*}{$\begin{array}{c}\text { Dose } \\
\left(\mathrm{ml} / \mathrm{g} \mathrm{kg}^{-1} \text { seed }\right)\end{array}$} & \multicolumn{10}{|c|}{ Corrected per cent mortality / Period (Days After Treatment) } \\
\hline & & 23 & 25 & 27 & 29 & 31 & 33 & $\mathbf{P}$ & $\mathbf{T}$ & PTI & ORE \\
\hline Imidacloprid 600 FS & 1.5 & 21.4 & 15.6 & 4.1 & 0 & 0 & 0 & 27 & 50.16 & 1354.32 & 5 \\
\hline Imidacloprid 600 FS & 2.0 & 34.0 & 21.5 & 7.3 & 1.4 & 0 & 0 & 29 & 54.95 & 1593.55 & 2 \\
\hline Imidacloprid $600 \mathrm{FS}$ & 2.5 & 38.7 & 25.2 & 13.0 & 5.2 & 2.1 & 0 & 31 & 57.52 & 1783.12 & 1 \\
\hline $\begin{array}{l}\text { Imidacloprid } 600 \mathrm{FS}+P \text {. } \\
\text { fluorescens }\end{array}$ & $2.0+10 g$ & 33.5 & 19.3 & 6.7 & 2.0 & 0 & 0 & 29 & 54.44 & 1578.76 & 3 \\
\hline Thiamethoxam 300 FS & 3.0 & 27.6 & 11.1 & 5.4 & 0 & 0 & 0 & 27 & 52.15 & 1408.05 & 4 \\
\hline
\end{tabular}

$\mathbf{P}-$ Period of persistence (days) $\quad$ PTI - Persistent Toxicity Index $\quad$ T - Mean per cent mortality $\quad$ ORE - Order of Relative Efficacy 
Table.4 Persistent toxicity of imidacloprid 600 FS to Green leafhopper, Nephotettix virescens (Dist.) on rice

\begin{tabular}{|c|c|c|c|c|c|c|c|c|c|c|c|c|}
\hline \multirow[t]{2}{*}{ Treatment } & \multirow{2}{*}{$\begin{array}{c}\text { Dose }\left(\mathrm{ml} / \mathrm{g} \mathrm{kg}^{-1}\right. \\
\text { seed })\end{array}$} & \multicolumn{11}{|c|}{ Corrected per cent mortality / Period (Days After Treatment) } \\
\hline & & 1 & 3 & 5 & 7 & 9 & 11 & 13 & 15 & 17 & 19 & 21 \\
\hline Imidacloprid $600 \mathrm{FS}$ & 1.5 & 88.0 & 87.2 & 86.8 & 85.2 & 85.0 & 82.0 & 80.4 & 70.1 & 65.6 & 50.1 & 41.2 \\
\hline Imidacloprid $600 \mathrm{FS}$ & 2.0 & 90.4 & 90.2 & 89.7 & 89.1 & 89.1 & 87.0 & 83.3 & 76.2 & 72.5 & 65.1 & 54.1 \\
\hline Imidacloprid $600 \mathrm{FS}$ & 2.5 & 91.3 & 91.3 & 91.0 & 90.7 & 90.3 & 88.7 & 85.1 & 80.0 & 75.3 & 69.3 & 58.2 \\
\hline $\begin{array}{l}\text { Imidacloprid } 600 \mathrm{FS}+P \text {. } \\
\text { fluorescens }\end{array}$ & $2.0+10 \mathrm{~g}$ & 90.1 & 90.0 & 89.8 & 88.7 & 88.6 & 86.6 & 83.0 & 75.3 & 71.6 & 64.3 & 53.5 \\
\hline Thiamethoxam 300 FS & 3.0 & 89.2 & 89.0 & 88.1 & 87.3 & 87.1 & 85.1 & 81.7 & 72.0 & 68.1 & 62.1 & 43.2 \\
\hline
\end{tabular}

\begin{tabular}{|c|c|c|c|c|c|c|c|c|c|c|c|}
\hline \multirow[t]{2}{*}{ Treatment } & \multirow{2}{*}{$\begin{array}{c}\text { Dose } \\
\left(\mathrm{ml} / \mathrm{g} \mathrm{kg}^{-1} \text { seed }\right)\end{array}$} & \multicolumn{10}{|c|}{ Corrected per cent mortality / Period (Days After Treatment) } \\
\hline & & 23 & 25 & 27 & 29 & 31 & 33 & $\mathbf{P}$ & $\mathbf{T}$ & PTI & ORE \\
\hline Imidacloprid 600 FS & 1.5 & 29.2 & 16.2 & 4.1 & 0 & 0 & 0 & 27 & 51.24 & 1485.96 & 4 \\
\hline Imidacloprid $600 \mathrm{FS}$ & 2.0 & 49.1 & 31.6 & 17.6 & 4.2 & 0 & 0 & 29 & 58.19 & 1687.51 & 2 \\
\hline Imidacloprid $600 \mathrm{FS}$ & 2.5 & 50.1 & 38.1 & 25.4 & 12.0 & 3.4 & 0 & 31 & 61.19 & 1896.89 & 1 \\
\hline $\begin{array}{l}\text { Imidacloprid } 600 \mathrm{FS}+P \text {. } \\
\text { fluorescens }\end{array}$ & $\begin{aligned} & 2.0 \\
+ & 10 g\end{aligned}$ & 48.3 & 32.0 & 16.2 & 4.7 & 0 & 0 & 29 & 57.81 & 1676.49 & 3 \\
\hline Thiamethoxam 300 FS & 3.0 & 30.0 & 19.3 & 6.1 & 0 & 0 & 0 & 27 & 53.43 & 1442.61 & 5 \\
\hline
\end{tabular}

\begin{tabular}{|llll}
\hline $\mathbf{P}-$ Period of persistence (days) & PTI - Persistent Toxicity Index & T - Mean per cent mortality & ORE - Order of Relative Efficacy \\
\hline
\end{tabular}




\section{Persistent toxicity}

The results on persistent toxicity of imidacloprid as seed treatment revealed that the chemical persisted for 51 days at $2.5 \mathrm{ml}$

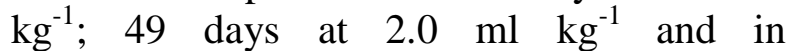
combination of $2.0 \mathrm{ml}+10 \mathrm{~g}$ P. flourescens $\mathrm{kg}^{-1} ; 47$ days at both $1.5 \mathrm{ml} \mathrm{kg}$ and standard check thiamethoxam $3.0 \mathrm{ml} \mathrm{kg}$ against brown planthopper. Similar range of persistence was recorded against green leafhopper also. Present results are in agreement with the work of Zhang et al (2011) who reported that thiamethoxam (Cruiser $(\circledR)$ at $0.342 \mathrm{mg}$ a.i. seed $^{-1}$ and imidacloprid (Gaucho Grande (®) at $0.375 \mathrm{mg}$ a.i. seed ${ }^{-1}$ exhibited similar efficacy against Bemisia tabaci (Gennadius) in cotton for up to 45 days after planting in the laboratory and greenhouse experiments and up to 56 days under field conditions. Kumar (1998) revealed persistence for foliar spray of imidacloprid $200 \mathrm{SL}$ at 100 and $150 \mathrm{ml} \mathrm{ha}^{-1}$ as 22 days against aphid and 30 days against leafhopper in cotton.

The longer persistence of imidacloprid and thiamethoxam may be due to the metabolic products of active ingredient that also enhanced toxicity against the pest.

Seed treatments are often preferable to foliar sprays because they are safer, easy to handle and allow more precise targeting of the insecticidal active ingredient with the pest organism by forming a protective zone of active ingredient around the seed grain against insect pests. The coating of active ingredient can be easily taken up by the roots during plant establishment in nursery, hence uptake into plant tissues is increased and residual activity against pests is enhanced. The preceding concept can be evidenced by findings of Sur and Stork (2003), in which uptake, translocation and metabolism of imidacloprid has been deliberated. The results of translocation experiments for imidacloprid with different application types show, that there is a good acropetal translocation of the active substances to shoots and leaves (excellent xylem mobility) on the one hand and on the other hand a poor basipetal translocation to sinks, i.e. storage organs, roots and fruits (negligible phloem mobility). Three common metabolic pathways of conversion of imidacloprid in plant system had been observed, viz., transformation of active substance into olefin, nitrosamine and 6 chloronicotinic acid. Nevertheless, irrespective of mode of application, they share the common metabolism and translocation pathways, the uptake after soil or seed treatment is about $5 \%$ of the applied dose and the a.s. shows good acropetal mobility within the xylem and poor basipetal translocation within the phloem. A quick degradation of the active substance was observed after root uptake of the active substance in seed treatment or soil application. In the case of spray application only a part of the active substance is translocated into the plant and metabolized there, so the degree of metabolism tends to be lower in this case.

\section{In vitro evaluation of imidacloprid on germination and seedling vigour}

The results of the germination percentage observed at different incubation hours in darkness revealed that higher germination was observed after 24 hours incubation (96 per cent). Hence 24 hours incubation is suggested before imidacloprid treatment wherein no deleterious effect on the seedling establishment was observed. The present findings are in line with Stevens et al (2008) who showed imidacloprid (2000 mg a.i. $\mathrm{l}^{-1}$ ) had no adverse effects on post germination growth if applied to pre germinated rice shortly before sowing and even up to 4000 $\mathrm{mg}$ a.i. $\mathrm{l}^{-1}$. Imidacloprid had no significant influence on germination, seedling length and 
vigour index after treatment. The parameters like germination percentage, root and shoot length and vigour index were recorded from imidacloprid treatment after 24 hours incubation, 24 hours incubation after treatment with imidacloprid and absolute control (Dry seed treatment). All these parameters were on par in the above three cases and were not statistically significant. However, trivial increase in seedling length and vigour index was observed in case of 24 hours seed incubation after treatment with imidacloprid.

Similar findings were reported by Sajjan et al (2010) in sunflower. As per the study, in all the concentrations of imidacloprid $600 \mathrm{FS}$ $(2.5,5.0,7.5,10.0$ and $12.5 \mathrm{ml} / \mathrm{kg}$ seeds) the germination level was above the minimum seed certification standards (more than 70\%) up to eighth month of storage and at ninth month after storage the germination was below 70 per cent. In contrast, the seedling length and vigour index were also significantly influenced by the imidacloprid concentrations. The mean seedling length and vigour index after nine month storage in imidacloprid 600 FS @ $2.5 \mathrm{ml} / \mathrm{kg}$ seed was $31.4 \mathrm{~cm}$ and 2540, respectively as against in untreated check $(32.6 \mathrm{~cm}$ and 2748 , respectively). However, seedling length and vigour index was observed to reduce with the increased dosage of imidacloprid.

Hence to conclude, seed treatment with imidacloprid 600 FS @ $2.5 \mathrm{ml} \mathrm{kg}^{-1}$ seed was persistent up to 50 days in laboratory condition. However, under field condition, this finding may not be correlated, since plants are exposed to UV and other abiotic factors, degradation of metabolites will be rapid that may cause reduced persistence. Incubation period of 24 hours in darkness is recommended before seed treatment with imidacloprid 600 FS to attain better efficiency and this treatment does not have any significant influence on seedling establishment and vigour.

\section{References}

Abbott, W. S. 1925. A method of computing the effectiveness of an insecticide. J. Econ. Ent., 18: 265 - 267.

Abdul-Baki, A. A. and Anderson. J. D. 1973. Viability and leaching of sugars from germinating barley. Crop Sci., 1: 3134.

Bonmatin, J-M., C. Giorio, V. Girolami, D. Goulson and Kreutzweiser, D.P. 2014 Environmental fate and exposure; neonicotinoids and fipronil. Environ Sci Pollut Res: 1-33.

Bromilow. R.H., and Chamberlain, K. 1995. Principles governing uptake and transport of chemicals. Plant contamination: modelling and simulation. Lewis Publishers, London, pp 37-64.

Duncan, D. B. 1951. A significance test for differences between ranked treatment means in an analysis of variance. Va. J. Sci., 2: 171-189.

Heinrichs, E.A., F.G. Medrano and Rapusas, H. R. 1985. Genetic evaluation for insect resistance in rice, International Rice Research Institute, Los Banos, Laguna, Philippines, pp. 45-173.

ISTA, 1999. International rules for seed testing. Seed Sci. and Technol. 27: Supplement rule, 27-31.

Kagabu, S., K. Moriya, K. Shibuya, Y. Hattori, S. Tsuboi and Shiokawa K. 1992. 1-(6-halonicotinyl)2nitromethylene-imidazolines as potential new insecticides. Biosci. Biotechnol. Biochem. 56: 361-363.

Kumar, K. 1998. Studies on bioefficacy and determination of residues of imidacloprid applied against sucking pests of cotton. Ph.D. Thesis, Tamil Nadu Agricultural University, 
Coimbatore, India, 114p.

Sajjan, A.S., R.A. Balikai, R.B. Jolli and Guggari, A.K. 2010. Effect of Seed Treatment with Imidacloprid 600 FS on Seed Quality During Storage in Sunflower. Int. J. Plant Prot. 2(2): $167-170$.

Stevens, M. M., R. F. Reinkie, N. E. Coombes, S. Helliwell and Mo, J. 2008. Influence of imidacloprid seed treatments on rice germination and early seedling growth. Pest Manag Sci., 64: 215-222.

Sur, R., and Stork, A. 2003. Uptake, translocation and metabolism of imidacloprid in plants. Bull. insectol. 56(1): 35-40.

Taniguchi, T., Y. Kita , T. Matsumoto and Kimura, K. 2012. Honeybee colony losses during 2008-2010 caused by pesticide application in Japan. Jpn J Apic. 27:15-27.

Tomizawa, M., and Casida, J.E. 2011. Neonicotinoid insecticides: highlights of a symposium on strategic molecular designs. J Agric Food Chem. 59: 2883-2886.

Van der Sluijs, J.P., N. Simon-Delso, D. Goulson, L. Maxim, J-M. Bonmatin and Belzunces, L.P. 2013. Neonicotinoids, bee disorders and the sustainability of pollinator services. Curr Opin Environ Sustain 5:293-305.

Zhang, L., S. M.Greenberg, Y. Zhang and Liu, T. X. 2011. Effectiveness of thiamethoxam and imidacloprid seed treatments against Bemisia tabaci (Hemiptera: Aleyrodidae) on cotton. Pest Manag. Sci., 67: 226-232.

\section{How to cite this article:}

Sangamithra, S., K. Samiayyan and Chandrasekaran, S. 2018. In vitro Evaluation of Persistent Toxicity of Imidacloprid 600 FS against Brown Plant Hopper and Green Leaf Hopper and its Impact on Germination and Seedling Vigour in Rice. Int.J.Curr.Microbiol.App.Sci. 7(01): 3361-3370. doi: https://doi.org/10.20546/ijcmas.2018.701.398 